\title{
RELIABILITY OF ULTRASOUND MEASUREMENT OF MUSCLE THICKNESS IN PATIENTS WITH SUPRASPINATUS TENDON PATHOLOGY
}

\author{
Domagoj Kretić, Tajana Turk, Tatjana Rotim and Gordan Šarić \\ Department of Diagnostic and Interventional Radiology, Osijek University Hospital Center, Osijek, Croatia
}

\begin{abstract}
SUMMARY - Objectives of the study were to observe supraspinatus muscle thickness in patients with supraspinatus tendon pathology using ultrasound (US) and examining inter- and intra-rater reliability, and to compare muscle thickness with cross-sectional area (CSA) and occupation ratio measured by both US and magnetic resonance imaging (MRI). The investigation was designed as a prospective cohort study. Two groups of patients were included in the study: 43 patients with tendon rupture and 44 patients without tendon rupture as a control group. A written consent was obtained from all patients. In both groups, muscle thickness, CSA and occupation ratio were measured with US, and CSA and occupation ratio with MRI. Study results showed statistically significant between-group differences. The mean supraspinatus muscle thickness measured by US was $14.01 \mathrm{~mm}$ and $19.83 \mathrm{~mm}$ in patients with and without tendon rupture, respectively. CSA and occupation ratio measured by US and MRI also showed statistically significant between-group differences. Pearson correlation coefficient between supraspinatus thickness and occupation ratio and CSA measured by US and MRI showed strong to moderate correlation. US measurements showed moderate to strong intra- and inter-rater reliability. In conclusion, supraspinatus muscle thickness measurement by US is a reliable method for muscle atrophy evaluation and strongly correlates with other acknowledged methods.
\end{abstract}

Key words: Rotator Cuff; Rotator Cuff Injuries; Ultrasonography; Magnetic Resonance Imaging; Tendon Injuries; Muscular Atrophy

\section{Introduction}

Shoulder joint is an example of spherical joint with a great range of movements, the greatest of all human joints ${ }^{1}$, which it has obtained at a certain cost of security $^{2}$. Due to its great range of movements and very shallow glenoid cavity, it is very prone to different injuries. Rotator cuff tendon pathology varies from mild tendinopathy, calcifying tendinopathy as advanced tendon degeneration to partial or complete tendon rupture. Causes for this can be divided into intrinsic and extrinsic ones ${ }^{3}$. Supraspinatus tendon is the most often affected rotator cuff tendon ${ }^{4}$. Complete tendon rupture includes complete discontinuity of tendon or

Correspondence to: Domagoj Kretic, $M D$, Department of Diagnostic and Interventional Radiology, Osijek University Hospital Center, Josipa Huttlera 4, HR-31000 Osijek, Croatia

E-mail:dkretic@gmail.com

Received September 19, 2017, accepted April 12, 2018 communication between articular and bursal side of the tendon ${ }^{5}$. Size or volume of complete rupture is directly connected to the amount of fatty infiltration ${ }^{6}$, although some authors propose the degree of tendon retraction as a more important factor ${ }^{7}$. It is known that reduced thickness of the muscle, atrophy and fatty degeneration (FD) significantly affect the quality of the outcome of surgical treatment of supraspinatus ten$\mathrm{don}^{8}$, so it is necessary to early recognize and evaluate muscle atrophy, which is considered as a very important prognostic factor for the success of surgery and a deterministic factor in the choice of treatment 9

Three modalities have been used in supraspinatus FD assessment: ultrasound (US), computerized tomography (CT) and magnetic resonance imaging (MRI). A semi-quantitative method of determining supraspinatus muscle FD by using CT has been described by Goutailler et al., proposing a five-degree grading system $(0-4)^{8}$. With the development of non- 
ionizing modalities, CT is slowly abandoned in favor of MRI and US. MRI gives the best images of soft tissues and is widely used for FD evaluation, first by Fuchs et al. ${ }^{10}$, who propose a three-degree grading system, which is also a semiquantitative method. Thomazeau et al. ${ }^{9}$ were the first to propose a quantitative method to calculate occupation ratio of supraspinatus fossa. They divided results in three grades regarding the occupation ratio. Khoury et al. ${ }^{11}$ proposed translation of this method to US, which proved as a highly reliable method of muscle atrophy evaluation. Concerning that, Yi et al. ${ }^{12}$ performed a study in which they measured supraspinatus thickness by US in scapular notch, and correlated the values obtained by measuring cross-sectional area (CSA) by MRI. Limitations of the study were that they measured muscle in hemiplegic patients and a small sample of only $10 \mathrm{pa}^{-}$ tients.

In our study, we had significantly more patients $(n=87)$ and divided them into two groups according to supraspinatus tendon status as a deterministic factor (complete rupture and tendinopathy). Supraspinatus thickness in scapular notch was measured by US and then CSA and occupation ratio were measured by US and MRI. Our hypothesis was that the US measured supraspinatus thickness would be usable as a good diagnostic performance and reliable method in the detection and grading of supraspinatus muscle atrophy.

\section{Patients and Methods}

This study was conducted at a university hospital and approved by the institutional Ethics Committee prior to patient recruitment. An initial sample size of 80 patients was chosen on the basis of analysis that assumed performance of an equivalence test. To detect the effect of 0.6 difference in numerical variables between the two groups, with a significance level of 0.05 and power of 0.75 , the minimal required sample size is 40 participants per group, i.e. a total of 80 patients (calculations made using $G^{*}$ Power version 3.1.2., Franz Faul, University of Kiel, Kiel, Germany) $)^{13}$. A written consent was obtained from each patient after being informed on the purpose and procedure of this study.

A total of 89 patients were included prospectively and randomly in the study. Two patients were excluded after enrolment, one for humeral neck fracture and previously undetected claustrophobia each. The re- maining 87 patients were divided into two groups according to the presence or absence of complete tendon rupture as a deterministic factor. Group 1 consisted of 43 patients with complete tendon rupture/full thickness tear and group 2 of 44 patients without tendon rupture (control group). Participants were aged between 40 and 80 years, regardless of gender. Exclusion criteria were hemiparesis or hemiplegia, other shoulder denervation causes, inflammatory rheumatic diseases, fractures or other bone structure disease of the tested shoulder, muscular dystrophy, open sores or infections in the shoulder area, frozen shoulder and unstable shoulder. For each patient, age, gender, height, weight, duration of symptoms (pain in the shoulder) and type of change (complete rupture or tendinopathy) were recorded. Patients with partial thickness tears were excluded.

\section{Ultrasound}

Ultrasound measurements were recorded first, including supraspinatus thickness, CSA and occupation ratio; all in parasagittal plane, perpendicular to muscle fibers, in the level of scapular notch. We used the technique described by Yi et al. ${ }^{12}$. The participant was sitting with the arm beside the body, with the forearm in supination and full extension in the elbow. The examiner palpated acromion and coracoid process and drew the line on the skin between them. The examiner applied the probe in that line, turned it parallel to supraspinatus muscle fibers, moved medially to scapular notch, where the muscle is thickest and turned it back parallel to the acromio-coracoid line. This is the site where muscle thickness, CSA of the muscle and supraspinatus fossa were measured. Later, occupation ratio was calculated as a quotient of CSA of the muscle and fossa.

Muscle thickness is measured in its thickest or middle portion ${ }^{14}$. Although in patients without tendon rupture or atrophy, the muscle is thickest in the middle portion of distance between the two acoustic shadows from clavicle and scapular spine ${ }^{12}$, in patients with muscle atrophy this is not the case because due to atrophy the muscle moves dorsally to the scapular spine. This is the reason for which we performed measuring at the muscle thickest part $^{15}$.

In the same way, we measured CSA and calculated occupation ratio using ellipse method ${ }^{11}$. All our US measurements were conducted on an Aloka Prosound 
Alpha 6 (Hitachi Healthcare, Tokyo, Japan) US machine, using UST-568 probe of 5-13 MHz frequency by radiologists with 5 and 15 years of experience in musculoskeletal US. All participants were evaluated by both examiners, who were blinded for other examiner findings; examination was repeated within one month. We evaluated all US measurements, i.e. supraspinatus muscle thickness, CSA of fossa and supraspinatus muscle and calculated occupational ratio after US measurements performed four times.

\section{Magnetic resonance imaging}

All MRI measurements were performed using a 1.5T MR system Siemens Avanto (Siemens Medical Solutions, Erlangen, Germany). Patients were in supine position with arms in full elbow extension and forearm in supination. After glenoid was identified, slices were made in T1WI parallel to glenoid in parasagittal plane by the following protocol: TE $15 \mathrm{~ms}$, TR $472 \mathrm{~ms}$, ST $3 \mathrm{~mm}$, FoV $160 \mathrm{~mm}$, FoV phase 100\%, PO 50\%, 20 slices performed.

After identifying Y-view, cross-sectional area of the supraspinatus fossa and supraspinatus muscle was measured using tracing tool and occupation ratio was calculated.

All patients from both groups were blindly evaluated by both examiners to determine whether or not there was complete supraspinatus tendon rupture; $\mathrm{pa}^{-}$ tients with partial rupture were not included in the study.

\section{Ethics}

The Ethics Committee of the Osijek University Hospital Centre reviewed and approved the study pro- tocol (No. 25-1:15404-7/2013) in accordance with the provisions of the Helsinki Declaration of 1975, as revised in 1983. An informed consent in writing was obtained from all participants prior to the enrolment.

\section{Statistics}

Statistical analysis was conducted using Windows SPSS version $23.0^{16}$ with the null hypothesis rejection at $\mathrm{p}<0.05$. As mentioned above, US measurements in each patient consisted of four blinded measurements for each variable; we used mean for easier data presentation and calculation, except for observing the intrarater and inter-rater reliability. Descriptive statistics, t-test for independent samples, correlation and factor analysis using Pearson correlation coefficient (PCC) and intraclass correlation coefficient (ICC) were used to present data and their relations.

\section{Results}

Median age of the subjects was 64.30 (SD 8.53) years in group 1 and 60.57 (SD 10.80) years in group 2. Median height was 166.49 (SD 10.85) cm in group 1 and 168.48 (SD 9.76) $\mathrm{cm}$ in group 2 (difference 1.98 $\mathrm{kg}, 95 \%$ confidence interval $(95 \% \mathrm{CI})$ for the difference from -6.38 to $2.40, \mathrm{t}=0.899, \mathrm{df}=85, \mathrm{p}<0.001)$. Median weight was 79.05 (SD 15.74) $\mathrm{kg}$ in group 1 and 79.68 (SD 12.61) $\mathrm{kg}$ in group 2 (difference 0.63 $\mathrm{kg}, 95 \% \mathrm{CI}$ for the difference from -6.74 to 5.48 , $\mathrm{t}=0.207, \mathrm{df}=85, \mathrm{p}<0.001)$. Group 1 consisted of 25 (58\%) women and 18 men, while group 2 consisted of 29 (66\%) women and 15 men. The mean duration of symptoms was 7.47 months in group 1 and 11.80 months in group 2 (Table 1 ).

Table 1. Median age, height, weight and number of participants, gender percentage and mean duration of symptoms between groups and combined

\begin{tabular}{|l|l|l|l|}
\hline & $\begin{array}{l}\text { Group 1 - with rupture } \\
(\mathrm{n}=43)\end{array}$ & $\begin{array}{l}\text { Group 2 - no rupture } \\
(\mathrm{n}=44)\end{array}$ & $\begin{array}{l}\text { Combined groups } \\
(\mathrm{N}=87)\end{array}$ \\
\hline Age (years), mean (SD) & $64.30(8.53)$ & $60.57(10.80)$ & $62.42(9.68)$ \\
Body height $(\mathrm{cm})$, mean $(\mathrm{SD})$ & $166.49(10.86)$ & $168.48(9.76)$ & $167.49(10.305)$ \\
Body weight $(\mathrm{kg})$, mean $(\mathrm{SD})$ & $79.05(15.74)$ & $79.68(12.81)$ & $79.37(14.26)$ \\
Number of participants & 43 & 44 & 87 \\
Sex, women, $\mathrm{n}(\%)$ & $25(58 \%)$ & $29(66 \%)$ & $54(62 \%)$ \\
Mean duration of symptoms, months (SD) & $7.47(9.54)$ & $11.80(9.69)$ & $9.65(9.77)$ \\
\hline
\end{tabular}

$\mathrm{SD}=$ standard deviation 


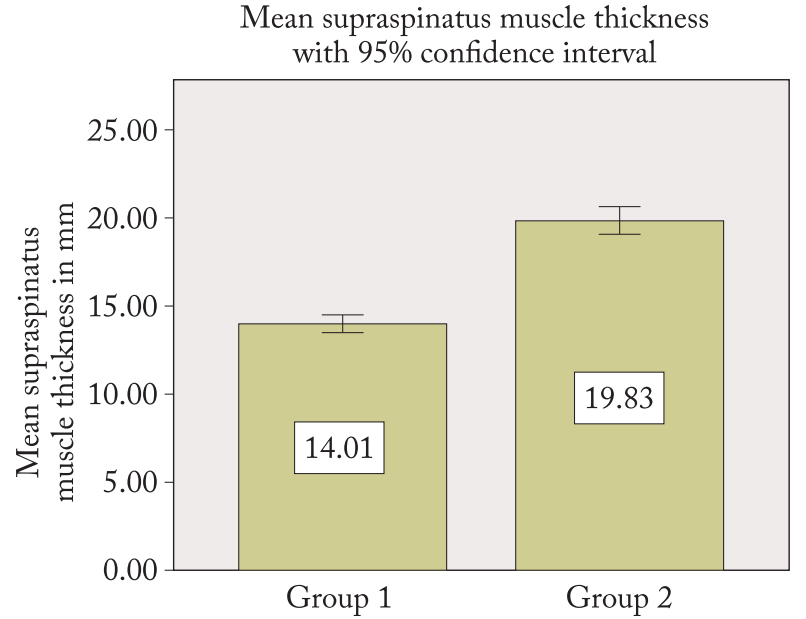

Fig. 1. Supraspinatus muscle thickness values in $\mathrm{mm}$ with 95\% confidence intervals between groups 1 and 2 (group 1, patients with complete supraspinatus tendon rupture, and group 2, patients without tendon rupture).
Ultrasound measurements showed the mean supraspinatus thickness of 14.01 (SD 1.63) $\mathrm{mm}$ in group 1 and 19.83 (SD 2.52) $\mathrm{mm}$ in group 2 (difference 5.82 $\mathrm{mm}, 95 \% \mathrm{CI}$ for the difference from -6.73 to 4.91 , $\mathrm{t}=12.758, \mathrm{df}=85, \mathrm{p}<0.001$ ) (Fig. 1). In group 1 , the mean CSA of the muscle and supraspinatus fossa was $2.66(\mathrm{SD} 0.67) \mathrm{cm}^{2}$ and $6.64(\mathrm{SD} 1.31) \mathrm{cm}^{2}$, respectively, yielding an occupation ratio of 0.40 (SD 0.07); in group 2, the respective results were 4.78 (SD 1.17) $\mathrm{cm}^{2}$ and 6.92 (SD 1.37) $\mathrm{cm}^{2}$, with occupation ratio of 0.69 (SD 0.06). These results showed a significant difference in CSA of the supraspinatus, as expected, whereas CSA measurements of supraspinatus fossa showed no significant difference (Table 2).

Magnetic resonance imaging measurements of CSA of the muscle, CSA of the supraspinatus fossa and calculated occupation ratio were 3.02 (SD 1.01) $\mathrm{cm}^{2}$ and 0.38 (SD 0.09) in group 1, and 5.35 (SD 1.49)

Table 2. Ultrasound measurements of supraspinatus thickness in mm, CSA of muscle and supraspinatus fossa in $\mathrm{cm}^{2}$ and calculated occupation ratio with t-test between groups, and 95\% confidence interval (95\% CI)

\begin{tabular}{|c|c|c|c|c|}
\hline Ultrasound measurement & $\begin{array}{l}\text { Group } 1 \text { - with rupture } \\
(\mathrm{n}=43)\end{array}$ & $\begin{array}{l}\text { Group } 2-\text { no rupture } \\
(\mathrm{n}=44)\end{array}$ & t-test & $\begin{array}{l}\text { Between group differences } \\
\text { Rupture minus non-rupture, } \\
\text { mean }(\mathrm{SD})(95 \% \mathrm{CI})\end{array}$ \\
\hline $\begin{array}{l}\text { Supraspinatus thickness } \\
(\mathrm{mm}) \text {, mean }(\mathrm{SD})\end{array}$ & $14.01(1.63)$ & $19.83(2.52)$ & 12.73 & $-5.82(-6.73$ to -4.91$)$ \\
\hline $\begin{array}{l}\text { CSA of the muscle }\left(\mathrm{cm}^{2}\right) \text {, } \\
\text { mean (SD) }\end{array}$ & $2.66(0.67)$ & $4.78(1.17)$ & 10.25 & $-2.12(-2.53$ to -1.71$)$ \\
\hline $\begin{array}{l}\text { CSA of the supraspinatus } \\
\text { fossa }\left(\mathrm{cm}^{2}\right) \text {, mean (SD) }\end{array}$ & $6.64(1.31)$ & $6,92(1.37)$ & 0.96 & $-0.28(-0.85$ to 0.29$)$ \\
\hline $\begin{array}{l}\text { Occupation ratio, mean } \\
\text { (SD) }\end{array}$ & $0.40(0.07)$ & $0.69(0.06)$ & 20.06 & $-0.28(-0.31$ to -0.26$)$ \\
\hline
\end{tabular}

$\mathrm{CSA}=$ cross-sectional area $\mathrm{SD}=$ standard deviation

Table 3. MRI measurements of CSA of muscle and supraspinatus fossa in $\mathrm{cm}^{2}$ and calculated occupation ratio between groups with t-test between groups and 95\% confidence interval (95\% CI)

\begin{tabular}{|l|l|l|l|l|}
\hline MRI measurement & $\begin{array}{l}\text { Group 1- with rupture } \\
(\mathrm{n}=43)\end{array}$ & $\begin{array}{l}\text { Group 2- no rupture } \\
(\mathrm{n}=44)\end{array}$ & t-test & $\begin{array}{l}\text { Between group differences } \\
\text { Rupture minus non-rupture, } \\
\text { mean (SD) (95\% CI) }\end{array}$ \\
\hline $\begin{array}{l}\text { CSA of the muscle }\left(\mathrm{cm}^{2}\right), \\
\text { mean (SD) }\end{array}$ & $3.02(1.01)$ & $5.35(1.49)$ & 8.53 & $-2.33(-2.88$ to -1.72$)$ \\
$\begin{array}{l}\text { CSA of the supraspinatus } \\
\text { fossa }\left(\mathrm{cm}^{2}\right) \text {, mean (SD) } \\
\text { Occupation ratio }\end{array}$ & $\begin{array}{l}8.01(1.63) \\
0.38(0.09)\end{array}$ & $\begin{array}{l}8.22(1.76) \\
0.65(0.07)\end{array}$ & 0.58 & $-0.21(-0.93$ to -0.51$)$ \\
\hline
\end{tabular}

$\mathrm{MRI}=$ magnetic resonance imaging; $\mathrm{CSA}=$ cross-sectional area; $\mathrm{SD}=$ standard deviation 
Table 4. Correlation of supraspinatus thickness measurement with occupation ratio and CSA measured with US expressed by $P C C$ in groups combined and separately

\begin{tabular}{|c|c|c|c|}
\hline $\begin{array}{l}\text { Supraspinatus } \\
\text { thickness }(\mathrm{mm})\end{array}$ & $\begin{array}{l}\text { Occupation } \\
\text { ratio }\end{array}$ & $\begin{array}{l}\text { CSA of } \\
\text { supraspinatus } \\
\left(\mathrm{cm}^{2}\right)\end{array}$ & $\mathrm{p}$-value \\
\hline $\begin{array}{l}\text { Groups } \\
\text { combined } \\
(\mathrm{N}=87)\end{array}$ & 0.88 & 0.96 & $<0.01$ \\
\hline $\begin{array}{l}\text { Group } 1 \text { - with } \\
\text { rupture }(n=43)\end{array}$ & 0.68 & 0.87 & $<0.01$ \\
\hline $\begin{array}{l}\text { Group } 2-\text { no } \\
\text { rupture }(n=44)\end{array}$ & 0.57 & 0.92 & $<0.01$ \\
\hline
\end{tabular}

$\mathrm{PCC}=$ Pearson correlation coefficient CSA = cross-sectional area; $\mathrm{US}=$ ultrasound

Table 5. Correlation of supraspinatus thickness measurement by US with occupation ratio and CSA measured with MRI expressed by PCC in groups combined and separately

\begin{tabular}{|l|l|l|l|}
\hline $\begin{array}{l}\text { Supraspinatus } \\
\text { thickness }(\mathrm{mm})\end{array}$ & $\begin{array}{l}\text { Occupation } \\
\text { ratio }\end{array}$ & $\begin{array}{l}\text { CSA of } \\
\text { supraspinatus } \\
\left(\mathrm{cm}^{2}\right)\end{array}$ & p-value \\
\hline $\begin{array}{l}\text { Groups } \\
\text { combined } \\
\text { (N=87) }\end{array}$ & 0.85 & 0.89 & $<0.01$ \\
$\begin{array}{l}\text { Group 1 - with } \\
\text { rupture (n=43) } \\
\text { Group 2 - no } \\
\text { rupture (n=44) }\end{array}$ & 0.49 & 0.60 & $<0.01$ \\
\hline
\end{tabular}

$\mathrm{PCC}=$ Pearson correlation coefficient CSA = cross-sectional area; $\mathrm{US}=$ ultrasound $\mathrm{MRI}=$ magnetic resonance imaging

$\mathrm{cm}^{2}$ and 0.65 (SD 0.07) in group 2, with t-test between the groups of 8.53 and 15.66 , respectively $(p<0.001)$. CSA of supraspinatus fossa showed no significant difference, with results of 8.01 (SD 1.63) $\mathrm{cm}^{2}$ in group 1 and 8.22 (SD 1.76) $\mathrm{cm}^{2}$ in group 2, with t of only 0.58 , as anticipated (Table 3 ).

Correlation analysis of the results revealed strong correlation between supraspinatus thickness and occupation ratio and CSA measured by US in all study subjects, with PCC of 0.879 for occupation ratio and 0.959 for CSA. In particular groups, PCC showed strong correlation between supraspinatus thickness and occupation ratio and CSA measured by US. In group 1, PCC between thickness and occupation ratio was 0.684 and between thickness and CSA 0.868, whereas in group $2 \mathrm{PCC}$ was 0.566 and 0.922 , respectively (Table 4). Correlation between muscle thickness measured by US and occupation ratio and CSA measured by MRI was moderate to strong, with PCC of 0.487 and 0.597 in group 1 and 0.611 and 0.873 in group 2. In all participants, PCC was 0.853 and 0.890 , respectively (Table 5).

Correlation between occupation ratio measured by US and MRI was moderate to strong; PCC was 0.912 in all subjects, 0.640 in group 1 and 0.611 in group 2 . We have to mention strong correlation of CSA of the muscle measured by US and MRI with PCC of 0.899 in all subjects, 0.642 in group 1 and 0.867 in group 2 .

Intraclass correlation coefficient for inter-rater reliability evaluating supraspinatus muscle thickness was 0.926 for first examiner and 0.930 for second examiner concerning all participants (both groups). PCC for inter-rater reliability evaluating supraspinatus muscle thickness for all participants was 0.934 on first measurement and 0.950 on second measurement. Intrarater reliability evaluating muscle thickness expressed by PCC was 0.926 for first examiner and 0.932 for second examiner in both groups. In group 1, PCC for inter-rater reliability was 0.828 on first measurement, while for second measurement of supraspinatus muscle thickness PCC was 0.775. In group 2, PCC for interrater reliability was 0.821 on first measurement and 0.914 on second measurement. In group 1, intra-rater PCC was 0.782 for first examiner and 0.780 for second examiner. In group 2, intra-rater PCC was 0.830 for first examiner and 0.831 for second examiner.

\section{Discussion}

In the hand of experienced operator concerning the protocol proposed by $\mathrm{Yi}$ et al. ${ }^{12}$, measurements assessing supraspinatus muscle thickness in scapular notch perpendicular to muscle fibers were highly different in the two groups, one including subjects with full-thickness supraspinatus tendon rupture, and the other one with supraspinatus tendinopathy (without rupture). There was significant difference between the groups, as expected; if we compare t-test of CSA and occupation ratios measured by US between the groups we can already suppose that supraspinatus thickness measurement is a highly reliable method of detecting 
muscle atrophy. The mean supraspinatus thickness was clearly lower in group 1 than in group 2. Our results were somewhat different from the results of Yi et al. ${ }^{12}$, where supraspinatus thickness median was 17.2 (SD $0.21) \mathrm{mm}$; we believe that was because of different weight and height of the subjects (in our study, median patient weight was $79.37 \mathrm{~kg}$ ) in group 2 (with tendinopathy), while the results in group 1 (with tendon rupture) clearly indicated reduced thickness due to muscle atrophy. The measured supraspinatus thickness correlated with the previously acknowledged methods of determining supraspinatus FD and muscle atrophy by MRI proposed by Thomazeau et al. ${ }^{9}$ and with US proposed by Khoury et al. ${ }^{11}$. These results of our study for all patients yielded PCC between occupation ratios measured by US and MRI of 0.912 , as compared with the study by Khoury et al. ${ }^{11}$, where PCC was 0.90 , which is very similar, almost identical. Results of our study showed stronger correlation between supraspinatus muscle thickness measured by US and CSA measured by MRI, with PCC of 0.89 , as compared with the study by Yi et al. ${ }^{12}$, where PCC was 0.76 because of the small number of participants in their study $(n=30)$. Our research confirmed US to be a highly reliable method in detecting supraspinatus muscle atrophy ${ }^{17,18}$. Our results on inter-rater and intra-rater reliability indicated the measurement of supraspinatus muscle thickness to be a highly reliable method. Although MRI is superior in soft tissue imaging, especially in shoulder and other joints ${ }^{19}$, US is a very useful and highly reliable method in soft tissue imaging, as an inexpensive, rapid and widely available modality. Good training in musculoskeletal imaging is required to identify and recognize pathologic disorders of joints and muscles ${ }^{20}$. Our results concerning intra-rater and inter-rater reliability are similar to those reported by Yi et al. ${ }^{12}$ and Papatzika et al. ${ }^{21}$. PCC for intra-rater reliability showed somewhat better results in group 2 than in group 1 , we believe because of the higher muscle volume in group 2 participants.

Limitations to this study were the lack of arthroscopy verification of full-thickness supraspinatus tear; wide weight, height and age span of patients; and a modest sample size.

In conclusion, our results showed that supraspinatus thickness strongly and very strongly correlated with CSA and occupational ratio measured by US in both patient groups, making this method useful in depicting muscle atrophy. Our results also showed that supraspinatus thickness strongly correlated with CSA and occupation ratio measured by MRI, although not as strongly as with US measurements. We strongly recommend using US in evaluating supraspinatus muscle atrophy routinely, as it can be used as a secondary sign for detecting full tendon rupture. Very good diagnostic performance of supraspinatus muscle thickness measurement suggests that it can be used as the first imaging modality describing supraspinatus muscle atrophy and FD.

\section{References}

1. Rockwood CA. The Shoulder. Philadelphia, PA: Saunders/Elsevier; 2009.

2. Cunningham DJ, Robinson A. Cunningham's Text-book of anatomy [Internet]. New York, W. Wood; 1914 [cited 2017 Mar 1]. 1640 p. Available from: http://archive.org/details/cunninghamstextb00cunn

3. Neer CS $2^{\text {nd }}$. Impingement lesions. Clin Orthop. 1983 Mar; (173):70-7.

4. Arthroscopic Rotator Cuff Repair Results | ShoulderDoc [Internet]. [cited 2017 Apr 5]. Available from: https://www.shoulderdoc.co.uk/article/1342

5. Bigliani LU, Cordasco FA, Mcllveen SJ, Musso ES. Operative repair of massive rotator cuff tears: long-term results. J Shoulder Elbow Surg. 1992 May;1(3):120-30. doi: 10.1016/1058-2746(92)90089-L. Epub 2009 Feb 25

6. Melis B, DeFranco MJ, Chuinard C, Walch G. Natural history of fatty infiltration and atrophy of the supraspinatus muscle in rotator cuff tears. Clin Orthop. 2010 Jun; 468(6):1498-505. doi: 10.1007/s11999-009-1207-x.

7. Lhee S-H, Singh AK, Lee DY. Does magnetic resonance imaging appearance of supraspinatus muscle atrophy change after repairing rotator cuff tears? J Shoulder Elbow Surg. 2017 Mar;26(3):416-23. doi: 10.1016/j.jse.2016.09.044. Epub 2016 Nov 30.

8. Goutallier D, Postel JM, Bernageau J, Lavau L, Voisin MC. Fatty muscle degeneration in cuff ruptures. Pre- and postoperative evaluation by CT scan. Clin Orthop. 1994 Jul;(304):78-83.

9. Thomazeau H, Rolland Y, Lucas C, Duval JM, Langlais F. Atrophy of the supraspinatus belly. Assessment by MRI in 55 patients with rotator cuff pathology. Acta Orthop Scand. 1996 Jun;67(3):264-8.

10. Fuchs B, Weishaupt D, Zanetti M, Hodler J, Gerber C. Fatty degeneration of the muscles of the rotator cuff: assessment by computed tomography versus magnetic resonance imaging. J Shoulder Elb Surg Am Shoulder Elb Surg Al. 1999 Dec; 8(6):599-605.

11. Khoury V, Cardinal É, Brassard P. Atrophy and fatty infiltration of the supraspinatus muscle: sonography versus MRI. Am J Roentgenol. 2008 Apr;190(4):1105-11. doi: 10.2214/AJR.07.2835. 
12. Yi TI, Han IS, Kim JS, Jin JR, Han JS. Reliability of the supraspinatus muscle thickness measurement by ultrasonography. Ann Rehabil Med. 2012 Aug;36(4):488-95. doi: 10.5535/arm.2012.36.4.488. Epub 2012 Aug 27.

13. Faul F, Erdfelder E, Lang A-G, Buchner A. G*Power 3: a flexible statistical power analysis program for the social, behavioral, and biomedical sciences. Behav Res Methods. 2007 May 1; 39(2):175-91.

14. Yanagisawa O, Okumura K, Torii S. Comparison of the morphology of the rotator cuff muscles across age groups. Clin Anat. 2013;n/a-n/a. doi: 10.1002/ca.22306. Epub 2013 Aug 30.

15. Kim YS, Heo NY, Kim MW. The test-retest reliability of supraspinatus cross-sectional area measurement by sonography. Ann Rehabil Med. 2011;35(4):524. doi: 10.5535/arm.2011.35.4.524. Epub 2011 Aug 31

16. IBM Release Notes - IBM SPSS Statistics 23 - United States [Internet]. 2015 [cited 2017 Apr 21]. Available from: http://www.ibm.com/support, //www.ibm.com/support/docview.wss?uid=swg 27043942

17. Blume C, Wang SS. Comparison of changes in supraspinatus muscle thickness in persons with subacromial impingement syndrome and asymptomatic adults. Physiother Theory Pract. 2014 Mar 28;1-8. doi: 10.3109/09593985.2014.902522. Epub 2014 Mar 28.

18. Wall LB, Teefey SA, Middleton WD, Dahiya N, Steger-May K, Kim HM, et al. Diagnostic performance and reliability of ultrasonography for fatty degeneration of the rotator cuff muscles. J Bone Joint Surg Am. 2012 Jun 20;94(12):e83. doi: 10.2106/JBJS.J.01899.

19. Rutten MJCM, Spaargaren G-J, Loon T van, Malefijt MC de W, Kiemeney LALM, Jager GJ. Detection of rotator cuff tears: the value of MRI following ultrasound. Eur Radiol. $2010 \mathrm{Feb}$ 1;20(2):450-7. doi: 10.1007/s00330-009-1561-9. Epub 2009 Sep 2.

20. Seibold CJ, Mallisee TA, Erickson SJ, Boynton MD, Raasch WG, Timins ME. Rotator cuff: evaluation with US and MR imaging. Radiogr Rev Publ Radiol Soc N Am Inc. 1999 Jun;19(3):685-705.

21. Papatzika F, Papandreou M, Ekizos A, Panteli C, Arampatzis A. Reliability and limits of agreement of the supraspinatus muscle anatomical cross-sectional area assessment by ultrasonography. Ultrasound Med Biol. 2015 Jul;41(7):1821-6. doi: 10.1016/j.ultrasmedbio.2015.02.017. Epub 2015 Apr 1.

\title{
POUZDANOST MJERENJA DEBLJINE MIŠIĆA ULTRAZVUKOM U BOLESNIKA S PATOLOGIJOM TETIVE SUPRASPINATUSA
}

\author{
D. Kretić, T. Turk, T. Rotim i G. Šarić
}

Ciljevi istraživanja bili su mjerenje debljine mišića supraspinatusa u bolesnika s patologijom tetive supraspinatusa pomoću ultrazvuka (UZV) i određivanje reproducibilnosti metode između ispitivača i kod samih ispitivača te usporedba mjerenja debljine mišića s presječnom površinom (CSA) i omjerom zauzeća fose supraspinatusa mjereno pomoću UZV i magnetskom rezonancijom (MR). Istraživanje je provedeno kao prospektivna kohortna studija u koju su bile uključene dvije skupine ispitanika: 43 ispitanika s rupturom tetive supraspinatusa i 44 ispitanika bez takve patologije kao kontrolna skupina. Svaki ispitanik je potpisao pristanak za sudjelovanje u ispitivanju. Debljina mišića, CSA i fosa supraspinatusa te omjer zauzeća izmjereni su u objema skupinama pomoću UZV, a CSA mišića i fose supraspinatusa te omjer zauzeća pomoću MR. Rezultati su pokazali statistički značajnu razliku između dviju skupina. U ispitanika s rupturom tetive prosječna debljina mišića supraspinatusa mjerena pomoću UZV bila je 14,01 $\mathrm{mm}$, a u onih bez rupture 19,83 $\mathrm{mm}$. CSA i omjer zauzeća izmjereni pomoću UZV i MR također su pokazali statistički značajnu razliku. Mjerenja pomoću UZV i MR pokazala su umjerenu do snažnu korelaciju. Reproducibilnost između ispitivača i kod pojedinog ispitivača bila je visoka. U zaključku, mjerenje debljine mišića supraspinatusa pomoću UZV je pouzdana metoda za procjenu atrofije mišića i snažno korelira s ostalim poznatim metodama.

Ključne riječi: rotatorna manšeta; rotatorna manšeta, ozljede; ultrazvuk; magnetska rezonancija, snimanje; tetive, ozljede; misićna atrofija 